\title{
Oxidative Stress Management in Chronic Liver Diseases and Hepatocellular Carcinoma
}

\author{
Daisuke Uchida $\mathbb{D}$, Akinobu Takaki *, Atsushi Oyama ${ }^{\circledR}$, Takuya Adachi, Nozomu Wada, \\ Hideki Onishi and Hiroyuki Okada \\ Department of Gastroenterology and Hepatology, Okayama University Graduate School of Medicine, \\ Dentistry and Pharmaceutical Sciences, Okayama 700-8558, Japan; d.uchida0309@gmail.com (D.U.); \\ at841205@gmail.com (A.O.); adataku719@yahoo.co.jp (T.A.); nonsan0808@yahoo.co.jp (N.W.); \\ ohnis-h1@cc.okayama-u.ac.jp (H.O.); hiro@md.okayama-u.ac.jp (H.O.) \\ * Correspondence: akitaka@md.okayama-u.ac.jp; Tel.: +81-86-235-7219
}

Received: 10 April 2020; Accepted: 26 May 2020; Published: 28 May 2020

\begin{abstract}
Chronic viral hepatitis B and C and non-alcoholic fatty liver disease (NAFLD) have been widely acknowledged to be the leading causes of liver cirrhosis and hepatocellular carcinoma. As anti-viral treatment progresses, the impact of NAFLD is increasing. NAFLD can coexist with chronic viral hepatitis and exacerbate its progression. Oxidative stress has been recognized as a chronic liver disease progression-related and cancer-initiating stress response. However, there are still many unresolved issues concerning oxidative stress, such as the correlation between the natural history of the disease and promising treatment protocols. Recent findings indicate that oxidative stress is also an anti-cancer response that is necessary to kill cancer cells. Oxidative stress might therefore be a cancer-initiating response that should be down regulated in the pre-cancerous stage in patients with risk factors for cancer, while it is an anti-cancer cell response that should not be down regulated in the post-cancerous stage, especially in patients using anti-cancer agents. Antioxidant nutrients should be administered carefully according to the patients' disease status. In this review, we will highlight these paradoxical effects of oxidative stress in chronic liver diseases, pre- and post-carcinogenesis.
\end{abstract}

Keywords: oxidative stress; chronic hepatitis; hepatocellular carcinoma

\section{Introduction}

With the progression of viral hepatitis treatment, hepatitis $\mathrm{C}$ virus (HCV) can now be eradicated in $>90 \%$ of treated patients, and hepatitis B can be controlled with low serum viral DNA, although viral eradication is still difficult [1,2]. The number of newly diagnosed hepatocellular carcinoma cases is decreasing; however, there are still many new patients, due to chronic viral hepatitis B and C [3]. The recent trend in increased obesity indicates that chronic viral hepatitis-related carcinogenesis is also partly due to non-alcoholic fatty liver disease (NAFLD) coexistence.

NAFLD can progress to HCC as a single disease or be concomitant with chronic viral hepatitis. It is mainly dependent on lifestyle changes, such as the spread of a Westernized diet and transportation progression from walking to a motorized society. As the numbers of obese people increase, so too does NAFLD, in addition to diabetes. Although Asian people are usually not very obese, they can develop obesity-related disease, such as diabetes, without severe obesity.

Present issues with the management of NAFLD can be summarized as follows: the natural history of the disease is not well defined, high-risk patients cannot be easily identified, and promising treatment protocols for the different stages of the disease are unclear. There have been many studies related to these problems; however, the natural history and the optimal management strategy at different stages, from simple steatosis, steatohepatitis, liver cirrhosis, HCC and beyond, are not 
clear [4-6]. The definition of NAFLD is under reconsideration, because patients with a history of alcohol consumption and those who habitually consume low amounts of alcohol are not definite non-alcoholic patients. Recently, a new disease category, metabolic-dysfunction-associated fatty liver disease (MAFLD) is advocated for patients with hepatic steatosis, in combination with one of the following three criteria: overweight/obesity, presence of type 2 diabetes mellitus, evidence of metabolic dysregulation [7]. Although the definition of MAFLD excludes individuals with excessive alcohol consumption, current drinkers and patients with a history of drinking can be included. The characteristics of the patients, natural history, and treatment strategy will change according to the new criteria. Given that the natural history might continue for several decades, a large cohort study should be conducted of individuals with NAFLD or MAFLD, and in vivo models should be used to predict the clinical course over decades.

Viral hepatitis-related inflammation and the fat-related stress response are both correlated with oxidative stress, a toxic response related to disease progression. However, oxidative stress also functions as an "anti-cancer" response that should be maintained in order to combat cancer [8]. In this review, we discuss the role of oxidative stress in chronic viral hepatitis and NAFLD, before and after carcinogenesis.

\section{Oxidative Stress in the Pathogenesis of Chronic Liver Diseases and Hepatocarcinogenesis}

\subsection{Oxidative Stress in the Cellular Pathogenesis of Chronic Liver Diseases}

Reactive oxygen species (ROS) are a source of oxidative stress generated in various organelles and stress pathways, such as mitochondria, peroxisomes, and the endoplasmic reticulum (ER) [9]. Mitochondria produce cellular ROS due to inefficiencies in electron flow along the electron transport chain (ETC). Under physiological conditions, the majority of incompletely reduced ROS, such as superoxide, are detoxified into water, and steady state necessary oxidant concentrations are maintained at relatively low levels ( $<1 \%$ of total oxygen consumed by mitochondria), via various antioxidant defenses and repair enzymes [10]. Physiological levels of ROS are necessary as a self-guarding response against damage from a toxic microbiome and as a plasma membrane repair response [11]. Excessive superoxide levels are produced within injured mitochondria through electron leakage, and then converted to hydrogen peroxide $\left(\mathrm{H}_{2} \mathrm{O}_{2}\right)$ by superoxide dismutase (SOD). There are several antioxidant enzymes, including glutathione peroxidase (GPx) or catalase that can metabolize $\mathrm{H}_{2} \mathrm{O}_{2}$ to non-toxic $\mathrm{H}_{2} \mathrm{O}$. There are also toxic hydroxyl radical producing reactions, namely the Fenton and/or Haber-Weiss reactions. Peroxisomes play a major role in fatty acid metabolism and produce oxidative stress via similar enzymatic pathways to mitochondria [12]. ER produces ER-stress associated oxidative stress when it contains the enzymes endoplasmic reticulum oxidoreductin $1 \alpha$ and protein disulfide isomerase [13]. These oxidants produce many toxic factors, such as TonEBP, resulting in cell injury and inflammation [14]. As all of these organelles produce ROS, there are many approaches to antioxidant therapy targeting these pathways, including the administration of inhibitors of mitochondrial dysfunction, ER stress, and NADPH oxidases (NOX) inhibitors; these approaches show varying degrees of clinical effectiveness [9].

In hepatocytes, ROS are produced by free fatty acid metabolism in mitochondria and microsomes [15]. Hepatocyte apoptosis due to inflammation also produces ROS, resulting in the inflammatory and fibrotic responses of Kupffer cells and hepatic stellate cells (HSCs).

Hepatic non-parenchymal cells, such as hepatic stellate cells (HSCs), liver resident macrophages (Kupffer cells), fibroblasts, and liver sinusoidal endothelial cells (LSECs), have been shown to be correlated with chronic inflammation and oxidative stress [16,17].

In liver fibrosis progression, the activation of HSCs into contractile and matrix-producing myofibroblasts is a central role. HSCs can be activated by mediators, such as transforming growth factor $\beta 1$ (TGF- $\beta \beta 1$ ) secreted from damaged hepatocytes, activated Kupffer cells, and aggregated platelets. TGF- $\beta 1$ plays key roles in regulating myofibroblasts, which induce continuous extracellular 
matrix (ECM) deposition, resulting in liver fibrosis [18]. Recently, cytoglobin has been shown to be expressed in HSCs, which catabolize $\mathrm{H}_{2} \mathrm{O}_{2}$ and lipid hydroperoxides, molecules involved in HSC activation [19]. Cytoglobin acts as an antioxidant in HSCs, and its knockout mouse model exhibited the progression of NASH and an extremely high incidence of HCC [20]. In addition, the selective overexpression of cytoglobin in HSCs has been shown to attenuate liver fibrosis in a mouse model [21]. TGF- $\beta 1$ suppresses human cytoglobin expression through phosphorylated SMAD2 and the M1 repressor isoform of SP3, suggesting its key role in oxidative stress control in HSCs [22].

Oxidative stress control in HSCs has been demonstrated via several approaches. In multidrug resistance gene 2 knockout (Mdr2-/-) mice, a genetic model that resembles primary sclerosing cholangitis (PSC), portal fibroblasts and HSCs were both activated; while they became inactive, resulting in the improvement of disease, with the administration of antioxidant NOX inhibitor [16]. HSCs are stimulated by ferric chloride and citrate addition followed and revert to a quiescent status with iron chelators, suggesting that iron-related oxidative stress is involved in HSC activation [23].

Kupffer cells that are activated by inflammatory cytokines, such as interleukin $1 \beta$ (IL1 $\beta$ ) released from damaged hepatocytes, subsequently activate NFKB, resulting in the release of IL6 and hepatocyte transforming oncogenic pathways, such as STAT3 [24]. One of the NFKB regulating oncogenes, Astrocyte elevated gene-1 (AEG-1), has been shown to be involved in hepatocarcinogenesis and the knock-out of hepatocyte AEG-1 resulted in the improvement of hepatocarcinogenesis in vivo and increased sensitivity to oxidative stress in vitro, while the knockout of macrophage AEG-1 resulted in the improvement of hepatocarcinogenesis and functional anergy in vitro, indicating that such genes cause both hepatocytes and Kupffer cells to cause hepatocarcinogenesis [25].

LSECs form hepatic sinusoids and control sinusoidal blood flow and the activation of the neighboring HSCs. LSECs are recognized as gatekeepers of hepatic inflammatory reactions, guarding Kupffer cells and HSCs from aberrant activation via toxic molecules in the portal vein [26]. In chronic liver diseases, inflammation gives LSECs physiological shear stress and capillarization, resulting in the activation of HSCs to cause liver fibrosis [17].

\subsection{Overview of the Oxidative Stress in the Pathogenesis of Hepatocarcinogenesis}

Chronic strong exposure to ROS induces chronic inflammatory disease progression and carcinogenesis [27,28]. ROS has been shown to be correlated with digestive system cancers, such as gastrointestinal cancer, cholangiocarcinoma, pancreatic cancer and HCC [29-31]. HCC develops from chronic viral hepatitis and non-alcoholic steatohepatitis (NASH), which is a severe form of NAFLD [15,32]. The mechanisms underlying hepatocarcinogenesis have been thoroughly investigated in chronic viral hepatitis-related HCC, as chronic viral hepatitis has been recognized as a major cause of HCC for several decades. The representative mechanisms underlying HBV- and HCV-related chronic liver disease progression and hepatocarcinogenesis have been shown to involve viral protein's functions, such as immune interference, tumor initiation or tumor suppression interference and oxidative stress response induction [33]. As chronic viral hepatitis-related liver inflammation is controllable with anti-viral agents, residual liver fibrosis-related cytokines or stress response and steatosis-related oxidative stress have a strong influence on the present and future incidence of hepatocarcinogenesis.

\subsection{Chronic Viral Hepatitis and Hepatocarcinogenesis}

Recent advances in anti-viral treatment have enabled us to eradicate HCV-RNA and reduce HBV-DNA in serum to the lower limit of normal levels. Although HBV viral DNA can be reduced to undetectable levels in the blood with nucleos(t)ide analogues, HBV virion and translated viral proteins are able to persist in infected hepatocytes and surrounding immune cells, even under a clinical cure, with seroclearance of the HBV envelope antigen (HBsAg) and the emergence of anti-HBs antibodies [34]. Although direct-acting antivirals (DAA) can induce a sustained virologic response (SVR) in $>95 \%$ of chronic hepatitis C patients, the risk of HCC—despite being reduced—still exists [35]. 


\subsubsection{HBV-Related Chronic Hepatitis}

Recent Advances in the Management of HBV-Related Chronic Hepatitis

HBV has been well-controlled with the administration of nucleos(t)ide analogues for nearly two decades. However, HCC can occur in patients with well-controlled viremia. There are many reports on predicting the risk of HCC development in patients treated with nucleos(t)ide analogues. The PAGE-B score, which includes baseline age, sex, and platelet count, could discriminate against Caucasian patients with 5-year HCC incidence rates of $0 \%, 3 \%$, and 17\% [36]. In Asian patients, the modified PAGE-B, which includes the serum albumin level in addition to the PAGE-B variables, showed better predictive performance than PAGE-B and four other scores: REACH-B (variables: male sex, age, alanine aminotransferase, HBeAg status, and HBV-DNA), GAG-HCC (variables: age, male sex, HBV-DNA, HBV core promoter mutations, cirrhosis), CU-HCC (variables: age, albumin, bilirubin, HBV-DNA, cirrhosis), and PAGE-B $[37,38]$. Basically, the patients who develop HCC even when hepatitis was controlled with nucleos(t)ide analogues were elderly male patients with advanced liver fibrosis and liver reservoir dysfunction. The screening of patients according to these predictive scores is recommended to facilitate the strict follow-up of these high-risk patients and save the costs associated with unnecessary imaging. In addition, Asian patients with chronic hepatitis B easily develop metabolic syndrome and a steatosis-related transaminase increase, even with a low BMI, indicating an additional HCC risk increase [39].

Given that one of the strong predictive markers for HCC is a low platelet count, which reflects liver fibrosis in cirrhosis, other markers of liver fibrosis have been investigated. Liver stiffness has recently been acknowledged to be a reliable non-invasive marker (measured by ultrasound), that can be used to diagnose liver fibrosis. Given that an accurate assessment of liver fibrosis is essential for surveillance and management, the evaluation of liver stiffness is strongly recommended in many guidelines [40,41]. Transient elastography (TE) and advanced two-dimensional (2D) shear wave elastography (SWE) are now widely used to assess liver stiffness. Higher liver stiffness has been shown to predict HCC in nucleos $(\mathrm{t})$ ide analogue-treated patients, in addition to cirrhosis, old age, male sex, lower platelet count and lower albumin level [42]. A new deep learning radiomics elastography system that adopts a radiomic strategy for the quantitative analysis of heterogeneity in 2D-SWE, has shown a much better diagnostic accuracy than 2D-SWE in chronic hepatitis B [43]. With these new non-invasive diagnostic tools, we can narrow down the HBV-positive patients with a high risk of developing HCC, and thereby reduce costs and improve quality of life.

Oxidative Stress in the Pathogenesis of HBV-Related Chronic Hepatitis and HCC

The mechanisms underlying hepatocarcinogenesis include the direct effect of HBV-producing proteins and integration of the HBV genome into human genome cis- or trans- activating targeted oncogenic or anti-oncogenic genes. There are many genes that have been reported to be affected by HBV. A genome sequencing analysis revealed that most (84\%) HBV-infected HCC patients exhibited HBV DNA integration into the host genome, leading to cis activation or inactivation of cancer regulatory genes, and resulting in HCC development [44].

One of the featured pathways of HBV-HCC pathogenesis involves direct tumorigenesis-related genes, such as tumor suppressor gene TP53 and CDKN2A [45]. CDKN2A encodes cyclin-dependent kinase (CDK) inhibitor 2A, while the mammalian cell cycle controlling enzyme CDK2 has been shown to be correlated with HCC. CDK2 is regulated by E-type cyclins E1 and E2. The CCNE1 locus, which encodes cyclin E1, has also been identified as an HBV integration site in $2-5 \%$ of HCC patients. Loss of Cyclin E1 attenuated hepatitis and HCC development in a mouse model [46]. Such oncogenic gene regulation change is believed to be a leading mechanism underlying HBV-related hepatocarcinogenesis, especially in non-cirrhotic HBV-related HCC [47].

Of the significantly mutated exome sequence in HBV-related HCC patients, the oxidative stressrelated KEAP1 has been shown to be involved, although the percentage was not very high $(12 \%$, 
versus $61 \%$ for telomere maintenance-related genes, $54 \%$ for Wnt- $\beta$-catenin signals and $51 \%$ for PI3K-AKT-mTOR pathway signals) $[45,48]$. The KEAP1 gene encodes Keap1 protein, which binds to the antioxidant-inducing transcriptional factor nuclear factor erythroid 2-related factor (Nrf2). Under oxidative stress conditions, Nrf2 is released from Keap1 and translocates to the nucleus, resulting in antioxidant defense-related protein activation. This pathway activation has been reported to be a mechanism through which cancer cells escape from toxic oxidative stress or other stress responses, such as endoplasmic reticulum (ER) stress. One of the Keap1 regulatory protein tripartite motif-containing (TRIM)25 has been shown to be upregulated by ER stress, resulting in Nrf2 release followed by escape from cytotoxic ER stress and the survival of tumor cells [49]. A high TRIM25 expression correlated with a poor patient survival in HCC, indicating that oxidative stress was preferable for patients' survival.

Of the HBV-producing proteins, HBx protein has been shown to be correlated with oxidative stress [50]. The mechanism involves HBx co-localization with mitochondria, and the C-terminal region has been shown to be critical for mitochondrial ROS production [51]. HBV with HBx protein expressed in mitochondria binds to voltage-dependent anion channels (VDAC3) and alters the mitochondrial transmembrane potential, resulting in ROS generation and the activation of several transcription factors [52]. Given that HBV may reside in the liver of billions of people worldwide, the changes in the oxidative stress status at different stages of the disease still need to be investigated.

\subsubsection{HCV-Related Chronic Hepatitis}

Recent Advances in the Management of HCV-Related Chronic Hepatitis

Recently, it has been demonstrated that DAA treatment can achieve viral eradication in patients of highly aged patients or advanced cirrhosis patients [53]. After HCV eradication, the risk of HCC occurrence decreases [54]. However, as older patients and those with advanced disease can receive DAA treatment due to the low incidence of side effects, care for HCC is still very important [55].

Although long-term results are awaited, risk stratification for the risk of hepatocarcinogenesis and liver fibrosis after DAA treatment has been intensively investigated in many institutes. It is widely acknowledged that a historic interferon treatment-based sustained viral response (SVR) has reduced the risk of HCC; however, whether a DAA-induced SVR is the same or not is still in debate [56]. It has been reported that the risk of de novo HCC occurrence risk decreases by $50-78 \%$ in cirrhosis patients and $70-80 \%$ in non-cirrhosis patients. The absolute risk of HCC in patients with cirrhosis at the time of DAA treatment is reported to be $1.8-2.5 \%$. The risk of HCC in non-cirrhosis patients is low, however, those with a high Fibrosis-4 (Fib-4) score, which represents cirrhotic status, have higher risk and require strict care [57,58]. A higher incidence of early occurrence of HCC after DAA treatment in patients with cirrhosis complicating undefined/non-malignant hepatic nodules has also been reported, indicating a new risk factor for HCC [59].

Several reports have assessed liver stiffness and the post-SVR clinical course in chronic hepatitis C. Liver stiffness, defined by TE, showed significant improvement after a DAA-induced SVR, especially in F4 stage cirrhosis patients, while it was less effective in patients with low platelet counts, indicating that severe fibrosis could not be improved [60]. From a report on the histological analysis of the resected liver, in patients who underwent liver resection due to HCC after an SVR, the liver stiffness measured by TE improved to the normal range, although histological fibrosis was evident as F4-cirrhosis [61]. A longitudinal analysis from Japan on liver stiffness before and after DAA showed that liver stiffness measurements decreased after an SVR24, while patients who developed HCC maintained higher liver stiffness than others [62]. In patients with higher liver stiffness, fibrosis-related activated hepatic stellate cells may be present; these cells produce cytokines, such as transforming growth factor (TGF)- $\beta$, which plays a prometastatic role in HCC by inducing epithelial-mesenchymal transition (EMT) [63]. An immunohistochemical study assessing fibrosis and LSEC capillarization before and after the administration of interferon/pegylated interferon induced-SVR showed that collagen (a fibrosis marker) 
decreased in $89 \%$ of patients, while, CD34 (an LSEC capillarization marker) did not change [64]. Residual capillarized LSECs after an SVR maybe a risk factor for hepatocarcinogenesis. Although there are no known effective markers of capillarized LSECs or thin fibrous septa, the platelet count and liver stiffness are candidate markers. Physicians should remember that a relatively high liver stiffness measurement is a risk factor for hepatocarcinogenesis and that F4 cirrhosis with fibrous septa might remain even after liver stiffness is reduced to the normal range (Figure 1).

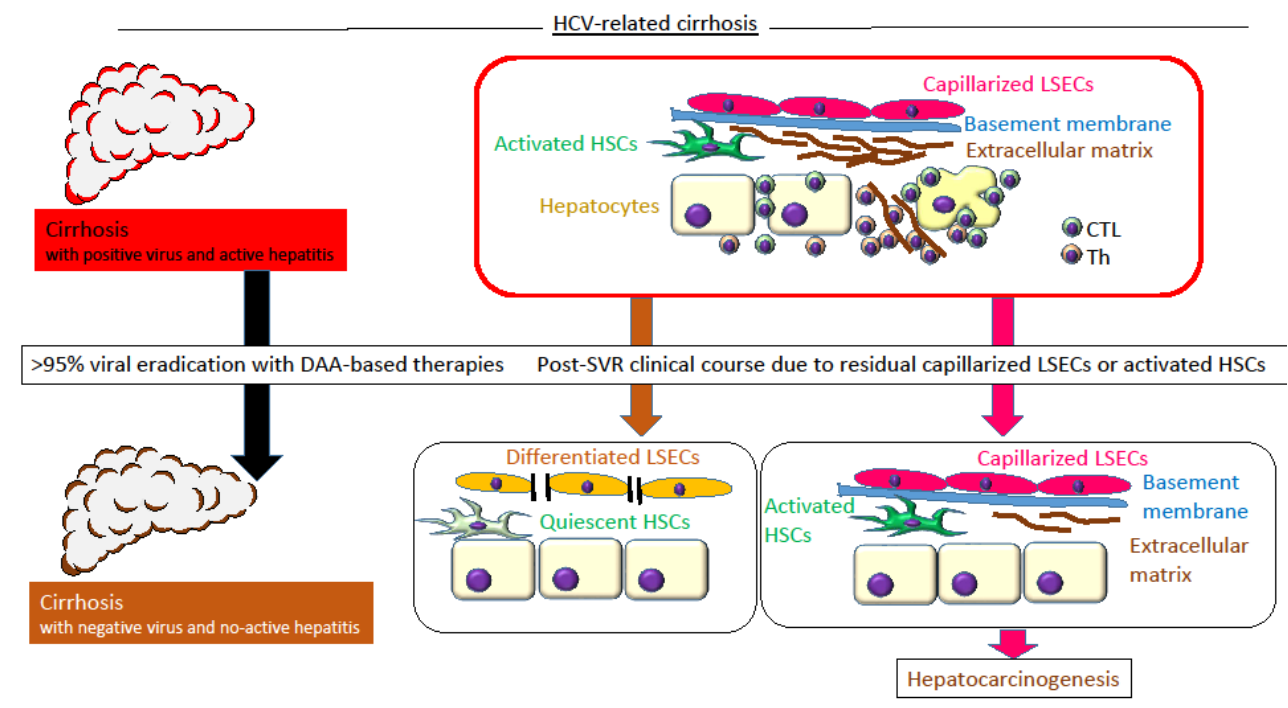

Figure 1. A conceptual diagram of probable post-sustained virologic response (SVR) hepatocarcinogenesis in hepatitis $\mathrm{C}$ virus (HCV)-related cirrhosis.

In active cirrhosis with HCV-positive and active hepatitis, the LSECs were capillarized and the basement membrane was composed of activated HSCs and activated inflammatory T cells. After viral eradication with DAA therapy, patients with differentiated LSECs and quiescent HSCs have a lower risk of hepatocarcinogenesis, while those with capillarized LSECs and activated HSCs have a higher risk of hepatocarcinogenesis. HCV (hepatitis C virus), DAA (direct-acting antivirals), HSCs (hepatic stellate cells), LSECs (liver sinusoidal endothelial cells), CTL (cytotoxic T cells), Th (helper T cells)

Oxidative Stress in the Pathogenesis of HCV-Related Chronic Hepatitis and HCC

HCV itself has direct oncogenic potential, but the effect is weaker than that of HBV. HCV-related HCC involves the upregulation of many detoxification-related genes or immune response- related genes according to a microarray analysis, suggesting the strong impact of chronic inflammation and several stress responses in HCV-related hepatocarcinogenesis [65]. HCV antigens, especially core proteins, have been shown to be a major player in pathogenesis and hepatocarcinogenesis in infected hepatocytes in vitro [66]. Similar findings have been obtained in in vivo models. Indeed, an HCV core protein transgenic mouse model showed progressive hepatic steatosis resulting in HCC [67,68]. In $\mathrm{HCV}$ transgenic mice, the HCV core protein transgenic was shown to interact with mitochondria and oxidized the glutathione pool and reduced NADPH content. This indicated the direct role of oxidative stress induction [69]. HCV nonstructural (NS) proteins also have correlations with oxidative stress-related pathways in infected hepatocytes and HCC cells. One of the newly discovered host antioxidant pathways, the 3b-hydorxysterol-d24-reductase (DHCR24), has been shown to be induced via direct-interaction with HCV NS proteins, resulting in an antioxidant role via the scavenging of toxic ROS in HCV-infected cells [70]. This is to make HCV infected cells resistant against toxic ROS.

As oxidative stress can be produced via iron-induced Fenton reaction, iron overload has been shown to be an HCV-related disease-aggravating factor [71]. HCV proteins play a role in increasing hepatic iron levels by reducing the levels of hepcidine, a regulator of hepatic iron, thereby resulting in strong oxidative 
stress [72]. Additional administration of an iron-rich diet induced aggravation of hepatocarcinogenesis, suggesting the importance of dietary iron regulation to prevent hepatocarcinogenesis [73]. Given that HCV infection can induce hepatic steatosis and oxidative stress, chronic hepatitis $\mathrm{C}$ progression resembles NAFLD progression.

\subsection{Oxidative Stress in the Pathogenesis of NAFLD-Related Steato-Hepatitis and HCC}

NAFLD can be accompanied by chronic hepatitis B or $\mathrm{C}$ infection, resulting in an additional risk of chronic inflammation and HCC development. The mechanism underlying the progression of NAFLD is recognized as the "two-hits" theory: the first hit is lipid deposition, and the second hit involves several stress responses, including oxidative stress, ER stress, autophagy, and chronic inflammation related cytokines [74]. Given that there are several patterns of progression mechanisms aside from the two hits theory, "multiple parallel hits" theory has also been proposed [75]. These hits induce insulin resistance and lipid peroxidation, leading to liver steatosis and increased free fatty acid accumulation and resulting in the activation of the $\beta$-oxidation cycle in mitochondria [76]. Mitochondria play an important role in fat oxidation via the $\beta$-oxidation cycle and generate adenosine triphosphate (ATP).

The first hit of lipid deposition in the liver is induced via dietary intake. Advanced NAFLD patients have been shown to consume more carbohydrates/energy higher saturated fatty acid and lower polyunsaturated fatty acids $[77,78]$. Adipose tissue in NAFLD produces adipokines, such as tumor necrosis factor alpha $(\mathrm{TNF} \alpha)$, resistin, and adiponectin. These factors induce chronic inflammation and insulin resistance. Overloaded free fatty acid induces mitochondria damage and generates ROS, which is the main source of oxidative stress.

Insulin resistance is characteristic of both type 2 diabetes and NAFLD progression. The liver is a background organ of systemic insulin resistance, which can develop via several mechanisms, such as liver-specific inflammation-related NF- $\mathrm{B}$ activation followed by cyclic AMP (cAMP) signaling activation, hepatic glucose production and insulin substrate PDE3B inhibition [79], as well as liver-specific JNK activation followed by IRS-1 inhibition [80]. ROS are involved as inducers of such kinase activation in hepatocytes. Kupffer cells and macrophages in the liver are believed to play critical roles in insulin resistance. They are the initial drivers of hepatic inflammation, which become activated in the liver of obese patients. An immunohistochemical analysis of simple fatty liver and NASH revealed that the infiltration of CD68-positive macrophages, including Kupffer cells, was evident, even in the simple fatty liver stage of NAFLD [81]. Inactivating Kupffer cells and macrophages via M2 macrophage polarization can ameliorate obesity-induced insulin resistance and the endothelial ROS signaling pathway [82].

Hyperinsulinemia induces HCC development and progression via its hepatocyte proliferative function and favorable microenvironmental arrangement for tumorigenesis [83]. Recently, conserved AAA + ATPases Pontin (RUVBL1) and Reptin (RUVBL2) have been shown to be associated with key cellular processes, such as chromatin remodeling, transcriptional regulation, mitosis, cell migration and insulin signaling [84,85]. They were both found to be up-regulated in HCC, and Pontin expression was shown to be a strong independent factor associated with a poor prognosis [86]. In a mouse model of liver-specific Pontin haploinsufficiency, Pontin was shown to regulate insulin signaling through the Akt/mTOR pathway [85]. The haploin sufficient model showed an initially delayed onset of HCC but later caught up, developing larger tumors. This controversial effect was explained by Pontin reduction and induced the worsening of insulin resistance and later HCC progression. Insulin resistance and its related pathways, such as the Akt/mTOR pathway, and the ATPases signaling correlated with the initiation and later progression of HCC should be clarified in detail.

The genetic characteristics of advanced NASH have been described. One of the first strong factors reported was the lipid storage-related patatin-like phospholipase domain-containing 3 (PNPLA3) [87]. A single nucleotide polymorphism (SNP) in this gene has been shown to be significantly correlated with NASH progression among races [88]. PNPLA3 is reportedly correlated with the liver fat concentration. Recently, several other genes have also been shown to be correlated with NAFLD progression. One of 
them, TM6SF2, has been shown to be correlated with the liver triglyceride content and very-low-density lipoprotein (VLDL) secretion [89]. Patients containing alleles for these disease-susceptible risk genes who have increased liver fat contents have shown lower plasma triglyceride levels and a preserved insulin sensitivity [90]. These patients are described as being "silent" on blood examinations, and their potential existence should be kept in mind when screening for NAFLD. These genetic analyses have indicated that a hepatic increase in triglyceride and free fatty acid levels can lead to advanced NASH, while oxidative stress-related genes are not genetically involved. This suggest that the increase in oxidative stress is secondary to the above genetic mechanisms, fatty liver, and insulin resistance.

NASH-HCC-related genes have also been suggested, although their influence is still not widely accepted. One of them, DYSF gene, which encodes dysferlin linked with skeletal muscle repair, has been found to have significantly increased levels in Japanese NAFLD patients [91]. Even hepatocarcinogenesis might be correlated with the ecological environment in NASH.

The oxidative stress status has been analyzed in NAFLD and NAFLD-related HCC. Limited antioxidant defenses contribute to the processes of both NASH and hepatocarcinogenesis [92,93]. In liver mitochondria from NASH patients and mouse models, ultrastructural alterations, impairment of ATP synthesis and increased production of ROS have been reported [94,95]. Iron facilitates the Fenton reaction, resulting in oxidative stress, just as with $\mathrm{HCV}$ pathogenesis. The effect of iron on NAFLD pathogenesis remains controversial. Levels of iron have shown to be elevated in NASH, and reducing iron levels has resulted in fair outcomes [96]. Iron absorption-related transporters in liver and intestine have been shown to be changed via high-cholesterol diet in a rat model [97]. Excess iron intake should be avoided in order to prevent NAFLD progression. However, one-third of early-stage NAFLD patients have been shown to be iron-deficient, and this condition was correlated with female gender, obesity and type 2 diabetes [98]. An on-demand approach regarding whether to reduce or increase iron intake is also required.

\section{How to Manage Oxidative Stress in Pre-Cancer Stage}

Given that oxidative stress is involved in chronic viral hepatitis and NAFLD cross-sectional pathology, the management strategy can be commonly applied. Nutritional support or supplementation is used to eliminate ROS or activate antioxidant pathways, such as the Nrf2 pathway [99]. In the case of the simultaneous activation of Nrf2 and NFkB, Nrf2 acts antagonistically against NFkB [100]. In a chemically induced liver fibrosis model, antioxidant pomegranate juice, which contained anthocyanins and hydrolysable tannins, reduced hepatic fibrosis via Nrf2 activation and NFkB inactivation [101]. Adjusting for the balance of inflammatory or oxidative stress responses and the antioxidant response in the presence of disease according to the patient's oxidative stress condition is necessary; however, at present, this approach is not widely applied. The difficulty in defining the oxidative stress status is one reason for this. This background probably explains why the results of clinical studies of antioxidants to regulate carcinogenesis are often unsuccessful.

Trace elements are involved in oxidative stress-related conditions. Some of them, such as iron and zinc, are able to be measured as standard clinical markers and monitored. Iron has been shown to be toxic as an oxidative stress inducer in chronic liver disease, as mentioned in Section 2.4, and its level can be reduced by phlebotomy or iron chelator administration in chronic hepatitis and NASH [102]. Zinc plays a role in the reduction of inflammatory cytokines and oxidative stress via the synthesis of antioxidant enzymes and catalyzing enzymes, or by influencing transcriptional factors [103]. One of the inflammation related transcription factors NF- $\mathrm{KB}$ is reduced via its negative regulator zinc finger protein (A20) or PPAR- $\alpha \alpha$. An antioxidant enzyme Cu,Zn- SOD (SOD1) contains zinc as a co-factor. Zinc has been shown to be deficient in cases of chronic liver disease, especially cirrhosis, possibly because of the impaired absorption from the intestine and increased excretion in the urine [104]. Zinc is necessary for the function of Paneth cells, which prevent pathogenic microbial invasion in the intestine, a risk for subsequent hepatic inflammation via $\alpha$-defensin production [105]. However, the presence of excess dietary zinc increases oxidative stress with an increased intestinal permeability that should be 
avoided [106]. An appropriate and effective supplementation strategy is therefore necessary, even for trace elements.

Selenium is one of the essential elements required for the normal development of human and animal organisms. Selenium activates GPx, which is a representative antioxidant enzyme. The Gpx-1 enzyme activity and mRNA levels decrease dramatically in a selenium deficient diet, whereas other selenoproteins are less sensitive [107]. Feeding a selenium deficient diet with glutathione deficiency resulted in oxidative stress, during which the protein malondialdehyde levels increase in the liver and an individual thus becomes sensitive to drug induced liver injury, thereby indicating the necessity of selenium for antioxidant system activation [108]. Given that the blood selenium level was observed to decrease in liver cirrhosis patients, supplementation may be one approach to improve the antioxidant function in such cases [109].

\subsection{Dietary Intervention for Oxidative Stress}

The potential dietary antioxidant intake has been assessed in several studies. Even an increase in the food frequency questionnaire-defined dietary total antioxidant capacity was shown to be correlated with a lower liver histological assessment of NASH-related hepatocellular ballooning [110]. The intake of orange juice, a source of flavonoids and vitamin C, for eight weeks, resulted in a reduction of total cholesterol, LDL-cholesterol, $C$ reactive protein, and oxidative stress related markers, in a randomized study of 43 chronic hepatitis C patients [111]. Dietary vitamin C intake was shown to be inversely correlated with the presence of NAFLD, similarly to vitamin E, suggesting the favorable effect of both vitamins [112]. The positive effect of the intake of vitamin C on NAFLD prevention was shown to be dominant in middle-aged, non-obese males [113].

An iron-reduced diet, often coupled with phlebotomy, has been shown to be effective against chronic hepatitis C and NASH, resulting in a reduction of the risk of hepatocarcinogenesis [114]. Zinc supplementation has been evaluated in more than 1300 studies, although not many have shown statistically significant favorable results [115].

A small number of studies showed the preferable effects of zinc supplementation, suggesting the important role for antioxidant response. The transaminase level in chronic hepatitis $C$ patients decreased [116], and the serum levels of type IV collagen and tissue inhibitors of matrix-metalloproteinase-1 (TIMP-1) levels in chronic hepatitis patients also decreased [117]. In cirrhosis patients, zinc supplementation may help to improve protein catabolism [118]. As zinc is often involved in standard laboratory examinations, to measure, evaluate, and adequate supplementation are thus all necessary steps. Large scale studies defining the best approach in chronic liver diseases are thus called for in the future.

Selenium supplementation has been shown to be effective in some patients with chronic thyroiditis, due to its immune targeting effect [119]. During chemotherapy for cancer patients, selenium supplementation has been shown to be associated with an improvement in fatigue, as well as in the liver and renal function [120]. However, in primary biliary cirrhosis, the supplementation of selenium did not show any antioxidant activities, while the renal excretion was increased, suggesting that a cirrhotic liver could not take advantage of selenium adequately [121]. Although selenium administration helps in the recovery of hepatic steatosis via PPAR- $\alpha$ activation in some diabetic mouse models [122], selenium supplementation to humans has been cautioned to increase the risk of type 2 diabetes [123]. It therefore remains difficult to draw any definite conclusions about selenium supplementation as an antioxidant.

\subsection{Clinical Trials for Oxidative Stress}

Many clinical trials have been undertaken to investigate whether antioxidants prevent cancer or death; however, the results are confusing. In the Alpha-Tocopherol, Beta-Carotene Cancer Prevention Study (ATBC), alpha-tocopherol reduced the incidence of prostate cancer, whereas beta-carotene increased the incidence of lung cancer and total mortality [124]. The Selenium and Vitamin E Cancer 
Prevention Trial (SELECT), a randomized control trial (RCT) that aimed to show the potential for vitamin $\mathrm{E}$ to reduce the risk of prostate cancer, showed a $17 \%$ increase in the incidence of prostate cancer [125]. Another study showed that beta-carotene supplementation was associated with an increased risk of lung cancer [126]. An epidemiologic study showed that dietary vitamin E intake and vitamin E supplement use was associated with a reduced risk of liver cancer, although vitamin $C$ and multivitamin intake increased the risk of liver cancer [24]. To define the real effect of antioxidant supplementation, studies should be planned according to the oxidative stress-related conditions before the start of intervention.

Antioxidant therapy, such as the administration of vitamin E, has been shown to be effective in improving inflammation and histological activity in NASH and is recommended in several guidelines for NAFLD. However, the long-term effect of these therapies, including the beneficial effects on the risk of hepatocarcinogenesis, is unclear $[127,128]$. There are also other antioxidant agents that have been shown to have favorable effects on NASH and NASH-related hepatocarcinogenesis.

Antidiabetic agents are recommended for NAFLD patients complicated with diabetes. Most of the antidiabetic agents, but not insulin or insulin producers, have been shown to be effective for NAFLD. Metformin and pioglitazone have been accepted as representative antioxidant agents [129]. Metformin has also been shown to activate AMPK by inhibiting mitochondrial complex I and inducing AMPK-independent lysosomal changes, resulting in many favorable effects in carcinogenesis and the post-carcinogenesis control of cancers [130]. Metformin-related AMPK pathway activation is involved in many cell types, including T cells, B cells, hepatocytes, and even liver fibrosis-inducing hepatic stellate cells (HSCs). As an antioxidant agent, metformin activates the Nrf2 signaling pathway, resulting in the production of heme oxygenase-1 ( $\mathrm{HO}-1$; an antioxidant enzyme), in human endothelial cells and thereby increasing the antioxidant function of these cells. However, in several cancer cell lines, including HCC, metformin suppressed the Nrf2 expression in an AMPK-independent manner [131]. Research on the effect of metformin on normal and cancerous cells is still ongoing. At present, this agent is recognized as suitable for pre-cancer administration, to prevent hepatocarcinogenesis and post-cancer administration, to prevent HCC recurrence.

Peroxisome proliferator-activated receptors (PPARs) are nuclear receptors that play key roles in cellular metabolic homeostasis and inflammation. Pioglitazone is a diabetes agent that activates PPAR- $\gamma$. It has been shown to improve insulin resistance, and several studies reported a favorable effect on NASH. One six-month randomized study of pioglitazone plus hypocaloric diet showed a plasma aminotransferase decrease, insulin sensitivity improvement, hepatic fat content decrease, and a histopathological reduction in liver necro-inflammation [132]. However, an additional analysis of select patients in the same cohort revealed that pioglitazone induced whole-body weight gain, and the increased weight was due to an increase in adipose tissue mass and not water retention [133].

Other antioxidants have been shown to be effective in several small series of studies. The administration of L-carnitine (a mitochondrial long-chain fatty acid uptake-related molecule) was reported to be associated with the histological improvement of NASH in a mouse model [134] and an RCT [135]. Flavonoids (heterogeneous polyphenols) have been shown to exert an antioxidant function, protecting the liver in a $\mathrm{CCl}_{4}$-induced liver injury model [136]. A mixture of flavonolignans and minor polyphenolic compounds derived from the milk thistle plant (Silybum marianum) named silymarin has been shown to have antioxidant power [137]. The main component of silymarin, silybin, has been shown to restore nicotinamide adenine dinucleotide (NAD+) levels, decreasing the glucose uptake and lipid peroxidation and resulting in the improvement of NAFLD [138,139]. Silymarin was shown to be effective for improving NASH-related fibrosis in a randomized, double-blind, placebo-controlled study, although the number of patients was relatively small (49 for silymarin and 50 for placebo) [140].

Many studies using antioxidant agents have shown promising results for NAFLD, suggesting that these agents may be viable candidate compounds in addition to standard vitamin E. 


\section{How to Manage Oxidative Stress in the Cancer Stage}

After the development of HCC, the role of oxidative stress changes. An adequate degree of oxidative stress should be maintained in order to regulate the progression of HCC. The ideal choice of agent for controlling chronic hepatitis or related hepatocarcinogenesis without suppressing the physiological roles of oxidative stress is difficult to determine.

\subsection{Management of Oxidative Stress after Radical Therapy}

After surgery or radio frequency ablation (RFA) treatment, HCC recurs in more than $60 \%$ of cases [141]. HCC recurrence is a critical factor associated with a poor survival of HCC. The recurrence pattern can be divided into two patterns: intrahepatic early metastasis and multicentric origin related late recurrence [142]. The phenotype of early-recurring tumors and the surrounding non-cancerous region has been described in several reports. An immunohistochemical analysis of tumors that recurred within 1 year after radical RFA showed that these tumors had a higher frequency $(67 \%)$ of poorly differentiated type and higher rates of positivity for the proliferation marker Ki-67 than non-recurrence within 1 year, with a lower rate of positivity of the negative cell cycle regulator p27 Kip1 [143]. A genome-wide gene-expression profile of resected cancer tissue and the surrounding noncancerous liver tissue showed that the increased expression of the cytochrome P450 1A2 (CYP1A2) gene in noncancerous tissue was a predictive marker for non-recurrence [144]. CYP1A2 is a form of hepatic cytochrome P450 oxidative system that is involved in drug and cholesterol metabolism. CYP1A2 knockout mice showed increased oxidative stress in liver microsomes, suggesting that CYP1A2 is an antioxidant molecule [145]. The plasma concentration of GPx3, another antioxidant enzyme, has been investigated in resected HCC [146]. Lower levels of plasma GPx3 were predictive of tumor progression and tumor recurrence. Based on these results of antioxidant-related marker analyses, the antioxidant reservoir function in the adjacent liver is critical for achieving a good survival after radical local treatment.

\subsection{Management of Oxidative Stress in Combination with Anti-Cancer Agents}

Many anti-cancer agents have been shown to induce oxidative stress to kill cancer cells. Recently, molecular-targeted agents, such as sorafenib, regorafenib and Lenvatinib, have become available as the standard treatment for HCC [147]. These agents mainly act on serine-threonine kinases, such as Raf-1, and on receptor tyrosine kinases, such as vascular endothelial growth factor receptor (VEGFR) and platelet-derived growth factor receptor- $\beta$ (PDGFR- $\beta$ ), resulting in deficient tumor-related microvascular angiogenesis and proliferation of tumor cells. Oxidative stress induction for cancer cells has been shown to be one mechanism by which these agents exert their effects [148].

However, while these agents have shown promise for controlling advanced HCC, drug resistance is an increasing problem. A genome-wide CRISPR/Cas9-based screening of a sorafenib-treated HCC cell line identified KEAP1 as the top candidate drug resistance-related gene [149]. Given that KEAP1 disruption resulted in increased Nrf2 activity and Nrf2-driven genes and decreased ROS production, oxidative stress reduction is one of the mechanisms underlying resistance to sorafenib. Oxidative stress should therefore be maintained in order to ensure the ongoing efficacy of these agents.

Maintaining the antioxidant function in the area surrounding the tumor and maintaining oxidative stress in the tumor area are proposed strategy for controlling oxidative stress in HCC. It is not easy to foster such oxidative stress-related statuses through nutritional support. Eliminating oxidative stress, as is recommended in the pre-cancer stage, is conversely not recommended in the cancer stage (Figure 2). 


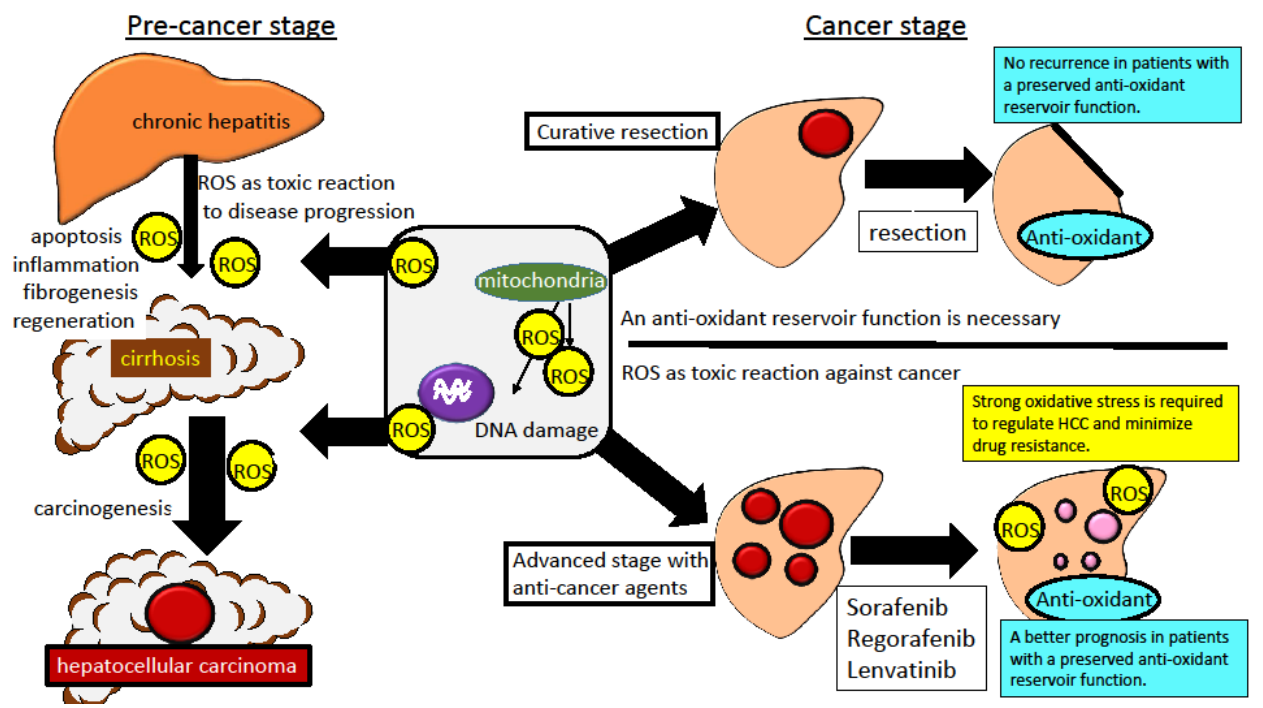

Figure 2. A conceptual diagram of oxidative stress in the pre- and post-carcinogenesis stage.

In the pre-carcinogenesis stage (as chronic viral hepatitis and NAFLD), oxidative stress is usually increased via inflammation or obesity-related fat deposition. Oxidative stress is a toxic and disease-exacerbating factor that should be regulated in the pre-cancer stage. However, in the cancer stage and under treatment with molecular-target agents, such as sorafenib, regorafenib or Lenvatinib, oxidative stress is an important anti-cancer response and a pharmaceutically beneficial response. The antioxidant reservoir function in the adjacent liver is required to regulate recurrence and new carcinogenesis. This paradox is difficult to resolve.

\section{Conclusions}

Oxidative stress is a disease progression-related toxic response in cases of chronic liver diseases such as chronic hepatitis B and C and NASH. In chronic hepatitis B and C, the viral load and associated chronic inflammation and oxidative stress can now be considerably controlled; however, reduced (but still present) fibrosis and LSEC capillarization and associated HSC or Kupffer cell activation still lead to the development of HCC. In NASH, in particular, antioxidant agents, such as vitamin E, are widely accepted as effective for controlling disease progression. However, after cancer development, oxidative stress is an anti-cancer response regulating cancer cell growth or proliferation and works as an adjuvant agent for anti-cancer molecular-targeted agents. Defining appropriate clinical characteristics (e.g., low platelet counts or high liver stiffness measurements before viral eradication and oxidative stress-related stages) before and after hepatocarcinogenesis will be necessary to improve the prognosis of patients with chronic liver disease.

Author Contributions: D.U. participated in the actual performance of writing the paper; A.T. planned and participated in the actual performance of writing the paper, A.O., T.A., N.W., and H.O. (Hideki Onishi) contributed to the data collection and providing summary of the data; H.O. (Hiroyuki Okada) supervised the planning and writing of the paper. All authors have read and agreed to the published version of the manuscript.

Funding: This research received no external funding.

Conflicts of Interest: The authors declare no conflict of interest.

\section{References}

1. Panel, A.-I.H.G. Hepatitis C Guidance 2018 Update: AASLD-IDSA Recommendations for Testing, Managing, and Treating Hepatitis C Virus Infection. Clin. Infect. Dis. 2018, 67, 1477-1492. [CrossRef]

2. Nguyen, M.H.; Wong, G.; Gane, E.; Kao, J.H.; Dusheiko, G. Hepatitis B Virus: Advances in Prevention, Diagnosis, and Therapy. Clin. Microbiol. Rev. 2020, 33. [CrossRef] [PubMed] 
3. Tateishi, R.; Uchino, K.; Fujiwara, N.; Takehara, T.; Okanoue, T.; Seike, M.; Yoshiji, H.; Yatsuhashi, H.; Shimizu, M.; Torimura, T.; et al. A nationwide survey on non-B, non-C hepatocellular carcinoma in Japan: 2011-2015 update. J. Gastroenterol. 2019, 54, 367-376. [CrossRef] [PubMed]

4. Pacifico, L.; Anania, C.; Martino, F.; Poggiogalle, E.; Chiarelli, F.; Arca, M.; Chiesa, C. Management of metabolic syndrome in children and adolescents. Nutr. Metab. Cardiovasc. Dis. 2011, 21, 455-466. [CrossRef] [PubMed]

5. Doycheva, I.; Watt, K.D.; Alkhouri, N. Nonalcoholic fatty liver disease in adolescents and young adults: The next frontier in the epidemic. Hepatology 2017, 65, 2100-2109. [CrossRef] [PubMed]

6. Negro, F. Natural history of NASH and HCC. Liver Int. 2020, 40, 72-76. [CrossRef]

7. Eslam, M.; Newsome, P.N.; Anstee, Q.M.; Targher, G.; Gomez, M.R.; Zelber-Sagi, S.; Wong, V.W.; Dufour, J.F.; Schattenberg, J.; Arrese, M.; et al. A new definition for metabolic associated fatty liver disease: An international expert consensus statement. J. Hepatol. 2020. [CrossRef]

8. Takaki, A.; Kawano, S.; Uchida, D.; Takahara, M.; Hiraoka, S.; Okada, H. Paradoxical Roles of Oxidative Stress Response in the Digestive System before and after Carcinogenesis. Cancers 2019, 11, 213. [CrossRef]

9. Luangmonkong, T.; Suriguga, S.; Mutsaers, H.A.M.; Groothuis, G.M.M.; Olinga, P.; Boersema, M. Targeting Oxidative Stress for the Treatment of Liver Fibrosis. Rev. Physiol. Biochem. Pharmacol. 2018, 175, 71-102. [CrossRef]

10. Brand, M.D. The sites and topology of mitochondrial superoxide production. Exp. Gerontol. 2010, 45, 466-472. [CrossRef]

11. Horn, A.; Jaiswal, J.K. Cellular mechanisms and signals that coordinate plasma membrane repair. Cell Mol. Life Sci. CMLS 2018, 75, 3751-3770. [CrossRef] [PubMed]

12. Demarquoy, J.; Le Borgne, F. Crosstalk between mitochondria and peroxisomes. World J. Biol. Chem. 2015, 6, 301-309. [CrossRef] [PubMed]

13. Zeeshan, H.M.; Lee, G.H.; Kim, H.R.; Chae, H.J. Endoplasmic Reticulum Stress and Associated ROS. Int. J. Mol. Sci. 2016, 17, 327. [CrossRef] [PubMed]

14. Lee, J.H.; Suh, J.H.; Choi, S.Y.; Kang, H.J.; Lee, H.H.; Ye, B.J.; Lee, G.R.; Jung, S.W.; Kim, C.J.; Lee-Kwon, W.; et al. Tonicity-responsive enhancer-binding protein promotes hepatocellular carcinogenesis, recurrence and metastasis. Gut 2019, 68, 347-358. [CrossRef] [PubMed]

15. Pessayre, D. Role of mitochondria in non-alcoholic fatty liver disease. J. Gastroenterol. Hepatol. 2007, 22 (Suppl. 1), S20-S27. [CrossRef]

16. Nishio, T.; Hu, R.; Koyama, Y.; Liang, S.; Rosenthal, S.B.; Yamamoto, G.; Karin, D.; Baglieri, J.; Ma, H.Y.; $\mathrm{Xu}, \mathrm{J}$. ; et al. Activated hepatic stellate cells and portal fibroblasts contribute to cholestatic liver fibrosis in MDR2 knockout mice. J. Hepatol. 2019, 71, 573-585. [CrossRef]

17. Poisson, J.; Lemoinne, S.; Boulanger, C.; Durand, F.; Moreau, R.; Valla, D.; Rautou, P.E. Liver sinusoidal endothelial cells: Physiology and role in liver diseases. J. Hepatol. 2017, 66, 212-227. [CrossRef]

18. Dewidar, B.; Meyer, C.; Dooley, S.; Meindl-Beinker, A.N. TGF-beta in Hepatic Stellate Cell Activation and Liver Fibrogenesis-Updated 2019. Cells 2019, 8, 1419. [CrossRef]

19. Kawada, N.; Kristensen, D.B.; Asahina, K.; Nakatani, K.; Minamiyama, Y.; Seki, S.; Yoshizato, K. Characterization of a stellate cell activation-associated protein (STAP) with peroxidase activity found in rat hepatic stellate cells. J. Biol. Chem. 2001, 276, 25318-25323. [CrossRef]

20. Thuy le, T.T.; Matsumoto, Y.; Thuy, T.T.; Hai, H.; Suoh, M.; Urahara, Y.; Motoyama, H.; Fujii, H.; Tamori, A.; Kubo, S.; et al. Cytoglobin deficiency promotes liver cancer development from hepatosteatosis through activation of the oxidative stress pathway. Am. J. Pathol. 2015, 185, 1045-1060. [CrossRef]

21. Thi Thanh Hai, N.; Thuy, L.T.T.; Shiota, A.; Kadono, C.; Daikoku, A.; Hoang, D.V.; Dat, N.Q.; Sato-Matsubara, M.; Yoshizato, K.; Kawada, N. Selective overexpression of cytoglobin in stellate cells attenuates thioacetamide-induced liver fibrosis in mice. Sci. Rep. 2018, 8, 17860. [CrossRef] [PubMed]

22. Okina, Y.; Sato-Matsubara, M.; Matsubara, T.; Daikoku, A.; Longato, L.; Rombouts, K.; Thanh Thuy, L.T.; Ichikawa, H.; Minamiyama, Y.; Kadota, M.; et al. TGF-beta-driven reduction of cytoglobin leads to oxidative DNA damage in stellate cells during non-alcoholic steatohepatitis. J. Hepatol. 2020. [CrossRef] [PubMed]

23. Gardi, C.; Arezzini, B.; Fortino, V.; Comporti, M. Effect of free iron on collagen synthesis, cell proliferation and MMP-2 expression in rat hepatic stellate cells. Biochem. Pharmacol. 2002, 64, 1139-1145. [CrossRef]

24. He, G.; Karin, M. NF-kappaB and STAT3-key players in liver inflammation and cancer. Cell Res. 2011, 21, 159-168. [CrossRef] [PubMed] 
25. Robertson, C.L.; Mendoza, R.G.; Jariwala, N.; Dozmorov, M.; Mukhopadhyay, N.D.; Subler, M.A.; Windle, J.J.; Lai, Z.; Fisher, P.B.; Ghosh, S.; et al. Astrocyte Elevated Gene-1 Regulates Macrophage Activation in Hepatocellular Carcinogenesis. Cancer Res. 2018, 78, 6436-6446. [CrossRef]

26. Hammoutene, A.; Rautou, P.E. Role of liver sinusoidal endothelial cells in non-alcoholic fatty liver disease. J. Hepatol. 2019, 70, 1278-1291. [CrossRef]

27. Muriel, P. Role of free radicals in liver diseases. Hepatol. Int. 2009, 3, 526-536. [CrossRef]

28. Yongvanit, P.; Pinlaor, S.; Bartsch, H. Oxidative and nitrative DNA damage: Key events in opisthorchiasis-induced carcinogenesis. Parasitol. Int. 2012, 61, 130-135. [CrossRef]

29. Bjelakovic, G.; Nikolova, D.; Simonetti, R.G.; Gluud, C. Antioxidant supplements for prevention of gastrointestinal cancers: A systematic review and meta-analysis. Lancet 2004, 364, 1219-1228. [CrossRef]

30. Uchida, D.; Takaki, A.; Ishikawa, H.; Tomono, Y.; Kato, H.; Tsutsumi, K.; Tamaki, N.; Maruyama, T.; Tomofuji, T.; Tsuzaki, R.; et al. Oxidative stress balance is dysregulated and represents an additional target for treating cholangiocarcinoma. Free Rad. Res. 2016, 1-12. [CrossRef]

31. Kuang, Y.; Sechi, M.; Nurra, S.; Ljungman, M.; Neamati, N. Design and Synthesis of Novel Reactive Oxygen Species Inducers for the Treatment of Pancreatic Ductal Adenocarcinoma. J. Med. Chem. 2018, 61, 1576-1594. [CrossRef] [PubMed]

32. Matteoni, C.A.; Younossi, Z.M.; Gramlich, T.; Boparai, N.; Liu, Y.C.; McCullough, A.J. Nonalcoholic fatty liver disease: A spectrum of clinical and pathological severity. Gastroenterology 1999, 116, 1413-1419. [CrossRef]

33. Arzumanyan, A.; Reis, H.M.; Feitelson, M.A. Pathogenic mechanisms in HBV- and HCV-associated hepatocellular carcinoma. Nat. Rev. Cancer 2013, 13, 123-135. [CrossRef] [PubMed]

34. Rehermann, B. Chronic infections with hepatotropic viruses: Mechanisms of impairment of cellular immune responses. Semin. Liver Dis. 2007, 27, 152-160. [CrossRef] [PubMed]

35. Jacobson, I.M.; Lim, J.K.; Fried, M.W. American Gastroenterological Association Institute Clinical Practice Update-Expert Review: Care of Patients Who Have Achieved a Sustained Virologic Response After Antiviral Therapy for Chronic Hepatitis C Infection. Gastroenterology 2017, 152, 1578-1587. [CrossRef]

36. Papatheodoridis, G.; Dalekos, G.; Sypsa, V.; Yurdaydin, C.; Buti, M.; Goulis, J.; Calleja, J.L.; Chi, H.; Manolakopoulos, S.; Mangia, G.; et al. PAGE-B predicts the risk of developing hepatocellular carcinoma in Caucasians with chronic hepatitis B on 5-year antiviral therapy. J. Hepatol. 2016, 64, 800-806. [CrossRef]

37. Kim, J.H.; Kim, Y.D.; Lee, M.; Jun, B.G.; Kim, T.S.; Suk, K.T.; Kang, S.H.; Kim, M.Y.; Cheon, G.J.; Kim, D.J.; et al. Modified PAGE-B score predicts the risk of hepatocellular carcinoma in Asians with chronic hepatitis B on antiviral therapy. J. Hepatol. 2018, 69, 1066-1073. [CrossRef]

38. Lee, H.W.; Kim, S.U.; Park, J.Y.; Kim, D.Y.; Ahn, S.H.; Han, K.H.; Kim, B.K. External validation of the modified PAGE-B score in Asian chronic hepatitis B patients receiving antiviral therapy. Liver Int. 2019, 39, 1624-1630. [CrossRef]

39. Clarke, W.T.; Miranda, J.; Neidich, E.; Hudock, R.; Peters, M.G.; Kelly, E.M. Metabolic syndrome and liver steatosis occur at lower body mass index in US Asian patients with chronic hepatitis B. J. Viral. Hepat 2019, 26, 1164-1169. [CrossRef]

40. Terrault, N.A.; Lok, A.S.F.; McMahon, B.J.; Chang, K.M.; Hwang, J.P.; Jonas, M.M.; Brown, R.S., Jr.; Bzowej, N.H.; Wong, J.B. Update on Prevention, Diagnosis, and Treatment of Chronic Hepatitis B: AASLD 2018 Hepatitis B Guidance. Clin. Liver Dis. (Hoboken) 2018, 12, 33-34. [CrossRef]

41. European Association for the Study of the Liver. EASL 2017 Clinical Practice Guidelines on the management of hepatitis B virus infection. J. Hepatol. 2017, 67, 370-398. [CrossRef] [PubMed]

42. Lee, H.W.; Park, S.Y.; Lee, M.; Lee, E.J.; Lee, J.; Kim, S.U.; Park, J.Y.; Kim, D.Y.; Ahn, S.H.; Kim, B.K. An optimized hepatocellular carcinoma prediction model for chronic hepatitis B with well-controlled viremia. Liver Int. 2020, 10.1111/liv.14451. [CrossRef] [PubMed]

43. Wang, K.; Lu, X.; Zhou, H.; Gao, Y.; Zheng, J.; Tong, M.; Wu, C.; Liu, C.; Huang, L.; Jiang, T.; et al. Deep learning Radiomics of shear wave elastography significantly improved diagnostic performance for assessing liver fibrosis in chronic hepatitis B: A prospective multicentre study. Gut 2019, 68, 729-741. [CrossRef] [PubMed]

44. Cancer Genome Atlas Research Network. Electronic address, w.b.e.; Cancer Genome Atlas Research, N. Comprehensive and Integrative Genomic Characterization of Hepatocellular Carcinoma. Cell 2017, 169, 1327-1341. [CrossRef] 
45. Schulze, K.; Imbeaud, S.; Letouze, E.; Alexandrov, L.B.; Calderaro, J.; Rebouissou, S.; Couchy, G.; Meiller, C.; Shinde, J.; Soysouvanh, F.; et al. Exome sequencing of hepatocellular carcinomas identifies new mutational signatures and potential therapeutic targets. Nat. Genet. 2015, 47, 505-511. [CrossRef]

46. Ehedego, H.; Mohs, A.; Jansen, B.; Hiththetiya, K.; Sicinski, P.; Liedtke, C.; Trautwein, C. Loss of Cyclin E1 attenuates hepatitis and hepatocarcinogenesis in a mouse model of chronic liver injury. Oncogene 2018, 37, 3329-3339. [CrossRef]

47. Zhao, L.H.; Liu, X.; Yan, H.X.; Li, W.Y.; Zeng, X.; Yang, Y.; Zhao, J.; Liu, S.P.; Zhuang, X.H.; Lin, C.; et al. Genomic and oncogenic preference of HBV integration in hepatocellular carcinoma. Nat. Commun. 2016, 7, 12992. [CrossRef]

48. Gao, Q.; Zhu, H.; Dong, L.; Shi, W.; Chen, R.; Song, Z.; Huang, C.; Li, J.; Dong, X.; Zhou, Y.; et al. Integrated Proteogenomic Characterization of HBV-Related Hepatocellular Carcinoma. Cell 2019, 179, 561-577. [CrossRef]

49. Liu, Y.; Tao, S.; Liao, L.; Li, Y.; Li, H.; Li, Z.; Lin, L.; Wan, X.; Yang, X.; Chen, L. TRIM25 promotes the cell survival and growth of hepatocellular carcinoma through targeting Keap1-Nrf2 pathway. Nat. Commun. 2020, 11, 348. [CrossRef]

50. Takaki, A.; Yamamoto, K. Control of oxidative stress in hepatocellular carcinoma: Helpful or harmful? World J. Hepatol. 2015, 7, 968-979. [CrossRef]

51. Jung, S.Y.; Kim, Y.J. C-terminal region of HBx is crucial for mitochondrial DNA damage. Cancer Lett. 2013, 331, 76-83. [CrossRef]

52. Rahmani, Z.; Huh, K.W.; Lasher, R.; Siddiqui, A. Hepatitis B virus X protein colocalizes to mitochondria with a human voltage-dependent anion channel, HVDAC3, and alters its transmembrane potential. J. Virol. 2000, 74, 2840-2846. [CrossRef] [PubMed]

53. Villani, R.; Monami, M.; Di Cosimo, F.; Fioravanti, G.; Mannucci, E.; Vendemiale, G.; Serviddio, G. Direct-acting antivirals for HCV treatment in older patients: A systematic review and meta-analysis. J. Viral. Hep. 2019, 26, 1249-1256. [CrossRef] [PubMed]

54. Kanwal, F.; Kramer, J.; Asch, S.M.; Chayanupatkul, M.; Cao, Y.; El-Serag, H.B. Risk of Hepatocellular Cancer in HCV Patients Treated With Direct-Acting Antiviral Agents. Gastroenterology 2017, 153, 996-1005. [CrossRef] [PubMed]

55. Nahon, P.; Layese, R.; Bourcier, V.; Cagnot, C.; Marcellin, P.; Guyader, D.; Pol, S.; Larrey, D.; De Ledinghen, V.; Ouzan, D.; et al. Incidence of Hepatocellular Carcinoma After Direct Antiviral Therapy for HCV in Patients With Cirrhosis Included in Surveillance Programs. Gastroenterology 2018, 155, 1436-1450. [CrossRef] [PubMed]

56. Singal, A.G.; Lim, J.K.; Kanwal, F. AGA Clinical Practice Update on Interaction Between Oral Direct-Acting Antivirals for Chronic Hepatitis C Infection and Hepatocellular Carcinoma: Expert Review. Gastroenterology 2019, 156, 2149-2157. [CrossRef]

57. Romano, A.; Angeli, P.; Piovesan, S.; Noventa, F.; Anastassopoulos, G.; Chemello, L.; Cavalletto, L.; Gambato, M.; Russo, F.P.; Burra, P.; et al. Newly diagnosed hepatocellular carcinoma in patients with advanced hepatitis C treated with DAAs: A prospective population study. J. Hepatol. 2018, 69, 345-352. [CrossRef]

58. Calvaruso, V.; Cabibbo, G.; Cacciola, I.; Petta, S.; Madonia, S.; Bellia, A.; Tine, F.; Distefano, M.; Licata, A.; Giannitrapani, L.; et al. Incidence of Hepatocellular Carcinoma in Patients With HCV-Associated Cirrhosis Treated With Direct-Acting Antiviral Agents. Gastroenterology 2018, 155, 411-421. [CrossRef]

59. Sangiovanni, A.; Alimenti, E.; Gattai, R.; Filomia, R.; Parente, E.; Valenti, L.; Marzi, L.; Pellegatta, G.; Borgia, G.; Gambato, M.; et al. Undefined/non-malignant hepatic nodules are associated with early occurrence of HCC in DAA-treated patients with HCV-related cirrhosis. J. Hepatol. 2020. [CrossRef]

60. Knop, V.; Mauss, S.; Goeser, T.; Geier, A.; Zimmermann, T.; Herzer, K.; Postel, N.; Friedrich-Rust, M.; Hofmann, W.P.; German Hepatitis, C.R. Dynamics of liver stiffness by transient elastography in patients with chronic hepatitis $C$ virus infection receiving direct-acting antiviral therapy-Results from the German Hepatitis C-Registry. J. Viral. Hepat. 2020. [CrossRef]

61. Martinez-Camprecios, J.; Bonis Puig, S.; Pons Delgado, M.; Salcedo Allende, M.T.; Minguez Rosique, B.; Genesca Ferrer, J. Transient elastography in DAA era. Relation between post-SVR LSM and histology. J. Viral. Hepat 2020, 27, 453-455. [CrossRef] [PubMed] 
62. Ogasawara, N.; Saitoh, S.; Akuta, N.; Sezaki, H.; Suzuki, F.; Fujiyama, S.; Kawamura, Y.; Hosaka, T.; Kobayashi, M.; Suzuki, Y.; et al. Advantage of liver stiffness measurement before and after direct-acting antiviral therapy to predict hepatocellular carcinoma and exacerbation of esophageal varices in chronic hepatitis C. Hepatol. Res. 2020, 50, 426-438. [CrossRef] [PubMed]

63. Liao, Z.; Chen, L.; Zhang, X.; Zhang, H.; Tan, X.; Dong, K.; Lu, X.; Zhu, H.; Liu, Q.; Zhang, Z.; et al. PTPRepsilon Acts as a Metastatic Promoter in Hepatocellular Carcinoma by Facilitating Recruitment of SMAD3 to TGF-beta Receptor 1. Hepatology 2020, 10.1002/hep.31104. [CrossRef]

64. D'Ambrosio, R.; Aghemo, A.; Rumi, M.G.; Ronchi, G.; Donato, M.F.; Paradis, V.; Colombo, M.; Bedossa, P. A morphometric and immunohistochemical study to assess the benefit of a sustained virological response in hepatitis C virus patients with cirrhosis. Hepatology 2012, 56, 532-543. [CrossRef]

65. Iizuka, N.; Oka, M.; Yamada-Okabe, H.; Mori, N.; Tamesa, T.; Okada, T.; Takemoto, N.; Tangoku, A.; Hamada, K.; Nakayama, H.; et al. Comparison of gene expression profiles between hepatitis B virus- and hepatitis $\mathrm{C}$ virus-infected hepatocellular carcinoma by oligonucleotide microarray data on the basis of a supervised learning method. Cancer Res. 2002, 62, 3939-3944.

66. Kato, N.; Yoshida, H.; Ono-Nita, S.K.; Kato, J.; Goto, T.; Otsuka, M.; Lan, K.; Matsushima, K.; Shiratori, Y.; Omata, M. Activation of intracellular signaling by hepatitis B and C viruses: C-viral core is the most potent signal inducer. Hepatology 2000, 32, 405-412. [CrossRef]

67. Moriya, K.; Yotsuyanagi, H.; Shintani, Y.; Fujie, H.; Ishibashi, K.; Matsuura, Y.; Miyamura, T.; Koike, K. Hepatitis C virus core protein induces hepatic steatosis in transgenic mice. J. Gen. Virol. 1997, 78, 1527-1531. [CrossRef]

68. Moriya, K.; Fujie, H.; Shintani, Y.; Yotsuyanagi, H.; Tsutsumi, T.; Ishibashi, K.; Matsuura, Y.; Kimura, S.; Miyamura, T.; Koike, K. The core protein of hepatitis $\mathrm{C}$ virus induces hepatocellular carcinoma in transgenic mice. Nat. Med. 1998, 4, 1065-1067. [CrossRef]

69. Korenaga, M.; Wang, T.; Li, Y.; Showalter, L.A.; Chan, T.; Sun, J.; Weinman, S.A. Hepatitis C virus core protein inhibits mitochondrial electron transport and increases reactive oxygen species (ROS) production. J. Biol. Chem. 2005, 280, 37481-37488. [CrossRef]

70. Rebbani, K.; Tsukiyama-Kohara, K. HCV-Induced Oxidative Stress: Battlefield-Winning Strategy. Oxid. Med. Cell Longev. 2016, 2016, 7425628. [CrossRef]

71. Hino, K.; Nishina, S.; Hara, Y. Iron metabolic disorder in chronic hepatitis C: Mechanisms and relevance to hepatocarcinogenesis. J. Gastroenterol. Hepatol. 2013, 28 (Suppl. 4), 93-98. [CrossRef] [PubMed]

72. Nishina, S.; Hino, K.; Korenaga, M.; Vecchi, C.; Pietrangelo, A.; Mizukami, Y.; Furutani, T.; Sakai, A.; Okuda, M.; Hidaka, I.; et al. Hepatitis C virus-induced reactive oxygen species raise hepatic iron level in mice by reducing hepcidin transcription. Gastroenterology 2008, 134, 226-238. [CrossRef] [PubMed]

73. Furutani, T.; Hino, K.; Okuda, M.; Gondo, T.; Nishina, S.; Kitase, A.; Korenaga, M.; Xiao, S.Y.; Weinman, S.A.; Lemon, S.M.; et al. Hepatic iron overload induces hepatocellular carcinoma in transgenic mice expressing the hepatitis C virus polyprotein. Gastroenterology 2006, 130, 2087-2098. [CrossRef] [PubMed]

74. Day, C.P.; James, O.F. Steatohepatitis: A tale of two "hits"? Gastroenterology 1998, 114, 842-845. [CrossRef]

75. Tilg, H.; Moschen, A.R. Evolution of inflammation in nonalcoholic fatty liver disease: The multiple parallel hits hypothesis. Hepatology 2010, 52, 1836-1846. [CrossRef]

76. Takaki, A.; Kawai, D.; Yamamoto, K. Molecular mechanisms and new treatment strategies for non-alcoholic steatohepatitis (NASH). Int. J. Mol. Sci. 2014, 15, 7352-7379. [CrossRef]

77. Toshimitsu, K.; Matsuura, B.; Ohkubo, I.; Niiya, T.; Furukawa, S.; Hiasa, Y.; Kawamura, M.; Ebihara, K.; Onji, M. Dietary habits and nutrient intake in non-alcoholic steatohepatitis. Nutrition 2007, 23, 46-52. [CrossRef]

78. Federico, A.; Dallio, M.; Caprio, G.G.; Gravina, A.G.; Picascia, D.; Masarone, M.; Persico, M.; Loguercio, C. Qualitative and Quantitative Evaluation of Dietary Intake in Patients with Non-Alcoholic Steatohepatitis. Nutrients 2017, 9, 1074. [CrossRef]

79. Ke, B.; Zhao, Z.; Ye, X.; Gao, Z.; Manganiello, V.; Wu, B.; Ye, J. Inactivation of NF-kappaB p65 (RelA) in Liver Improves Insulin Sensitivity and Inhibits cAMP/PKA Pathway. Diabetes 2015, 64, 3355-3362. [CrossRef]

80. Seki, E.; Brenner, D.A.; Karin, M. A liver full of JNK: Signaling in regulation of cell function and disease pathogenesis, and clinical approaches. Gastroenterology 2012, 143, 307-320. [CrossRef] 
81. Gadd, V.L.; Skoien, R.; Powell, E.E.; Fagan, K.J.; Winterford, C.; Horsfall, L.; Irvine, K.; Clouston, A.D. The portal inflammatory infiltrate and ductular reaction in human nonalcoholic fatty liver disease. Hepatology 2014, 59, 1393-1405. [CrossRef] [PubMed]

82. Lee, W.J.; Tateya, S.; Cheng, A.M.; Rizzo-DeLeon, N.; Wang, N.F.; Handa, P.; Wilson, C.L.; Clowes, A.W.; Sweet, I.R.; Bomsztyk, K.; et al. M2 Macrophage Polarization Mediates Anti-inflammatory Effects of Endothelial Nitric Oxide Signaling. Diabetes 2015, 64, 2836-2846. [CrossRef] [PubMed]

83. Chettouh, H.; Lequoy, M.; Fartoux, L.; Vigouroux, C.; Desbois-Mouthon, C. Hyperinsulinaemia and insulin signalling in the pathogenesis and the clinical course of hepatocellular carcinoma. Liver Int. 2015, 35, 2203-2217. [CrossRef] [PubMed]

84. Mao, Y.Q.; Houry, W.A. The Role of Pontin and Reptin in Cellular Physiology and Cancer Etiology. Front. Mol. Biosci. 2017, 4, 58. [CrossRef] [PubMed]

85. Mello, T.; Materozzi, M.; Zanieri, F.; Simeone, I.; Ceni, E.; Bereshchenko, O.; Polvani, S.; Tarocchi, M.; Marroncini, G.; Nerlov, C.; et al. Liver haploinsufficiency of RuvBL1 causes hepatic insulin resistance and enhances hepatocellular carcinoma progression. Int. J. Cancer 2020, 146, 3410-3422. [CrossRef] [PubMed]

86. Haurie, V.; Menard, L.; Nicou, A.; Touriol, C.; Metzler, P.; Fernandez, J.; Taras, D.; Lestienne, P.; Balabaud, C.; Bioulac-Sage, P.; et al. Adenosine triphosphatase pontin is overexpressed in hepatocellular carcinoma and coregulated with reptin through a new posttranslational mechanism. Hepatology 2009, 50, 1871-1883. [CrossRef]

87. Romeo, S.; Kozlitina, J.; Xing, C.; Pertsemlidis, A.; Cox, D.; Pennacchio, L.A.; Boerwinkle, E.; Cohen, J.C.; Hobbs, H.H. Genetic variation in PNPLA3 confers susceptibility to nonalcoholic fatty liver disease. Nat. Genet. 2008, 40, 1461-1465. [CrossRef]

88. Sookoian, S.; Pirola, C.J. Meta-analysis of the influence of I148M variant of patatin-like phospholipase domain containing 3 gene (PNPLA3) on the susceptibility and histological severity of nonalcoholic fatty liver disease. Hepatology 2011, 53, 1883-1894. [CrossRef]

89. Kozlitina, J.; Smagris, E.; Stender, S.; Nordestgaard, B.G.; Zhou, H.H.; Tybjaerg-Hansen, A.; Vogt, T.F.; Hobbs, H.H.; Cohen, J.C. Exome-wide association study identifies a TM6SF2 variant that confers susceptibility to nonalcoholic fatty liver disease. Nat. Genet. 2014, 46, 352-356. [CrossRef]

90. Zhou, Y.; Llaurado, G.; Oresic, M.; Hyotylainen, T.; Orho-Melander, M.; Yki-Jarvinen, H. Circulating triacylglycerol signatures and insulin sensitivity in NAFLD associated with the E167K variant in TM6SF2. J. Hepatol. 2015, 62, 657-663. [CrossRef]

91. Kawaguchi, T.; Shima, T.; Mizuno, M.; Mitsumoto, Y.; Umemura, A.; Kanbara, Y.; Tanaka, S.; Sumida, Y.; Yasui, K.; Takahashi, M.; et al. Risk estimation model for nonalcoholic fatty liver disease in the Japanese using multiple genetic markers. PLoS ONE 2018, 13, e0185490. [CrossRef] [PubMed]

92. Kawai, D.; Takaki, A.; Nakatsuka, A.; Wada, J.; Tamaki, N.; Yasunaka, T.; Koike, K.; Tsuzaki, R.; Matsumoto, K.; Miyake, Y.; et al. Hydrogen-rich water prevents progression of nonalcoholic steatohepatitis and accompanying hepatocarcinogenesis in mice. Hepatology 2012, 56, 912-921. [CrossRef] [PubMed]

93. Bugianesi, E. Non-alcoholic steatohepatitis and cancer. Clin. Liver Dis. 2007, 11, 191-207. [CrossRef] [PubMed]

94. Cortez-Pinto, H.; Chatham, J.; Chacko, V.P.; Arnold, C.; Rashid, A.; Diehl, A.M. Alterations in liver ATP homeostasis in human nonalcoholic steatohepatitis: A pilot study. JAMA 1999, 282, 1659-1664. [CrossRef]

95. Serviddio, G.; Bellanti, F.; Tamborra, R.; Rollo, T.; Romano, A.D.; Giudetti, A.M.; Capitanio, N.; Petrella, A.; Vendemiale, G.; Altomare, E. Alterations of hepatic ATP homeostasis and respiratory chain during development of non-alcoholic steatohepatitis in a rodent model. Eur. J. Clin. Invest. 2008, 38, 245-252. [CrossRef]

96. Nelson, J.E.; Wilson, L.; Brunt, E.M.; Yeh, M.M.; Kleiner, D.E.; Unalp-Arida, A.; Kowdley, K.V. Relationship between the pattern of hepatic iron deposition and histological severity in nonalcoholic fatty liver disease. Hepatology 2011, 53, 448-457. [CrossRef]

97. Higuchi, T.; Moriyama, M.; Fukushima, A.; Matsumura, H.; Matsuoka, S.; Kanda, T.; Sugitani, M.; Tsunemi, A.; Ueno, T.; Fukuda, N. Association of mRNA expression of iron metabolism-associated genes and progression of non-alcoholic steatohepatitis in rats. Oncotarget 2018, 9, 26183-26194. [CrossRef]

98. Siddique, A.; Nelson, J.E.; Aouizerat, B.; Yeh, M.M.; Kowdley, K.V.; Network, N.C.R. Iron Deficiency in Patients With Nonalcoholic Fatty Liver Disease Is Associated With Obesity, Female Gender, and Low Serum Hepcidin. Clin. Gastroenterol. Hepatol. 2013. [CrossRef] 
99. Peternelj, T.T.; Coombes, J.S. Antioxidant supplementation during exercise training: Beneficial or detrimental? Sports Med. 2011, 41, 1043-1069. [CrossRef]

100. Bellezza, I.; Mierla, A.L.; Minelli, A. Nrf2 and NF-kappaB and Their Concerted Modulation in Cancer Pathogenesis and Progression. Cancers 2010, 2, 483-497. [CrossRef]

101. Husain, H.; Latief, U.; Ahmad, R. Pomegranate action in curbing the incidence of liver injury triggered by Diethylnitrosamine by declining oxidative stress via Nrf2 and NFkappaB regulation. Sci. Rep. 2018, 8, 8606. [CrossRef] [PubMed]

102. Czaja, A.J. Review article: Iron disturbances in chronic liver diseases other than haemochromatosis-pathogenic, prognostic, and therapeutic implications. Aliment. Pharm. Ther. 2019, 49, 681-701. [CrossRef] [PubMed]

103. Olechnowicz, J.; Tinkov, A.; Skalny, A.; Suliburska, J. Zinc status is associated with inflammation, oxidative stress, lipid, and glucose metabolism. J. Physiol. Sci. 2018, 68, 19-31. [CrossRef] [PubMed]

104. Stamoulis, I.; Kouraklis, G.; Theocharis, S. Zinc and the liver: An active interaction. Dig. Dis. Sci. 2007, 52, 1595-1612. [CrossRef]

105. Zhong, W.; Wei, X.; Hao, L.; Lin, T.D.; Yue, R.; Sun, X.; Guo, W.; Dong, H.; Li, T.; Ahmadi, A.R.; et al. Paneth Cell Dysfunction Mediates Alcohol-related Steatohepatitis Through Promoting Bacterial Translocation in Mice: Role of Zinc Deficiency. Hepatology 2020, 71, 1575-1591. [CrossRef]

106. Podany, A.; Rauchut, J.; Wu, T.; Kawasawa, Y.I.; Wright, J.; Lamendella, R.; Soybel, D.I.; Kelleher, S.L. Excess Dietary Zinc Intake in Neonatal Mice Causes Oxidative Stress and Alters Intestinal Host-Microbe Interactions. Mol. Nutr. Food Res. 2019, 63, e1800947. [CrossRef]

107. Sunde, R.A.; Raines, A.M.; Barnes, K.M.; Evenson, J.K. Selenium status highly regulates selenoprotein mRNA levels for only a subset of the selenoproteins in the selenoproteome. Biosci. Rep. 2009, 29, 329-338. [CrossRef]

108. Goda, K.; Muta, K.; Yasui, Y.; Oshida, S.; Kitatani, K.; Takekoshi, S. Selenium and Glutathione-Depleted Rats as a Sensitive Animal Model to Predict Drug-Induced Liver Injury in Humans. Int. J. Mol. Sci. 2019, 20, 3141. [CrossRef]

109. Loguercio, C.; De Girolamo, V.; Federico, A.; Feng, S.L.; Crafa, E.; Cataldi, V.; Gialanella, G.; Moro, R.; Del Vecchio Blanco, C. Relationship of blood trace elements to liver damage, nutritional status, and oxidative stress in chronic nonalcoholic liver disease. Biol. Trace Elem. Res. 2001, 81, 245-254. [CrossRef]

110. De Oliveira, D.G.; de Faria Ghetti, F.; Moreira, A.P.B.; Hermsdorff, H.H.M.; de Oliveira, J.M.; de Castro Ferreira, L. Association between dietary total antioxidant capacity and hepatocellular ballooning in nonalcoholic steatohepatitis: A cross-sectional study. Eur. J. Nutr. 2019, 58, 2263-2270. [CrossRef]

111. Goncalves, D.; Lima, C.; Ferreira, P.; Costa, P.; Costa, A.; Figueiredo, W.; Cesar, T. Orange juice as dietary source of antioxidants for patients with hepatitis C under antiviral therapy. Food Nutr. Res. 2017, 61, 1296675. [CrossRef] [PubMed]

112. Ivancovsky-Wajcman, D.; Fliss-Isakov, N.; Salomone, F.; Webb, M.; Shibolet, O.; Kariv, R.; Zelber-Sagi, S. Dietary vitamin $\mathrm{E}$ and $\mathrm{C}$ intake is inversely associated with the severity of nonalcoholic fatty liver disease. Dig. Liver Dis. 2019, 51, 1698-1705. [CrossRef] [PubMed]

113. Wei, J.; Lei, G.H.; Fu, L.; Zeng, C.; Yang, T.; Peng, S.F. Association between Dietary Vitamin C Intake and Non-Alcoholic Fatty Liver Disease: A Cross-Sectional Study among Middle-Aged and Older Adults. PLoS ONE 2016, 11, e0147985. [CrossRef] [PubMed]

114. Kato, J.; Miyanishi, K.; Kobune, M.; Nakamura, T.; Takada, K.; Takimoto, R.; Kawano, Y.; Takahashi, S.; Takahashi, M.; Sato, Y.; et al. Long-term phlebotomy with low-iron diet therapy lowers risk of development of hepatocellular carcinoma from chronic hepatitis C. J. Gastroenterol. 2007, 42, 830-836. [CrossRef]

115. Diglio, D.C.; Fernandes, S.A.; Stein, J.; Azeredo-da-Silva, A.; de Mattos, A.A.; Tovo, C.V. Role of zinc supplementation in the management of chronic liver diseases: A systematic review and meta-analysis. Ann. Hepatol. 2020, 19, 190-196. [CrossRef]

116. Murakami, Y.; Koyabu, T.; Kawashima, A.; Kakibuchi, N.; Kawakami, T.; Takaguchi, K.; Kita, K.; Okita, M. Zinc supplementation prevents the increase of transaminase in chronic hepatitis $\mathrm{C}$ patients during combination therapy with pegylated interferon alpha-2b and ribavirin. J. Nutr. Sci. Vitaminol. 2007, 53, 213-218. [CrossRef]

117. Takahashi, M.; Saito, H.; Higashimoto, M.; Hibi, T. Possible inhibitory effect of oral zinc supplementation on hepatic fibrosis through downregulation of TIMP-1: A pilot study. Hepatol. Res. 2007, 37, 405-409. [CrossRef]

118. Kodama, H.; Tanaka, M.; Naito, Y.; Katayama, K.; Moriyama, M. Japan's Practical Guidelines for Zinc Deficiency with a Particular Focus on Taste Disorders, Inflammatory Bowel Disease, and Liver Cirrhosis. Int. J. Mol. Sci. 2020, 21, 2941. [CrossRef] 
119. Winther, K.H.; Papini, E.; Attanasio, R.; Negro, R.; Hegedus, L. A 2018 European Thyroid Association Survey on the Use of Selenium Supplementation in Hashimoto's Thyroiditis. Eur. Thyroid. J. 2020, 9, 99-105. [CrossRef] [PubMed]

120. Vieira, M.L.; Fonseca, F.L.; Costa, L.G.; Beltrame, R.L.; Chaves, C.M.; Cartum, J.; Alves, S.I.; Azzalis, L.A.; Junqueira, V.B.; Pereria, E.C.; et al. Supplementation with selenium can influence nausea, fatigue, physical, renal, and liver function of children and adolescents with cancer. J. Med. Food 2015, 18, 109-117. [CrossRef]

121. Valimaki, M.; Alfthan, G.; Vuoristo, M.; Ylikahri, R. Effects of selenium supplementation on blood and urine selenium levels and liver function in patients with primary biliary cirrhosis. Clin. Chim. Acta 1991, 196, 7-15. [CrossRef]

122. Shi, Y.; Zou, Y.; Shen, Z.; Xiong, Y.; Zhang, W.; Liu, C.; Chen, S. Trace Elements, PPARs, and Metabolic Syndrome. Int. J. Mol. Sci. 2020, 21, 2612. [CrossRef] [PubMed]

123. Vinceti, M.; Filippini, T.; Rothman, K.J. Selenium exposure and the risk of type 2 diabetes: A systematic review and meta-analysis. Eur. J. Epidemiol. 2018, 33, 789-810. [CrossRef] [PubMed]

124. Taylor, P.R.; Li, B.; Dawsey, S.M.; Li, J.Y.; Yang, C.S.; Guo, W.; Blot, W.J. Prevention of esophageal cancer: The nutrition intervention trials in Linxian, China. Linxian Nutrition Intervention Trials Study Group. Cancer Res. 1994, 54, 2029s-2031s.

125. Klein, E.A.; Thompson, I.M., Jr.; Tangen, C.M.; Crowley, J.J.; Lucia, M.S.; Goodman, P.J.; Minasian, L.M.; Ford, L.G.; Parnes, H.L.; Gaziano, J.M.; et al. Vitamin E and the risk of prostate cancer: The Selenium and Vitamin E Cancer Prevention Trial (SELECT). JAMA 2011, 306, 1549-1556. [CrossRef]

126. Omenn, G.S.; Goodman, G.E.; Thornquist, M.D.; Balmes, J.; Cullen, M.R.; Glass, A.; Keogh, J.P.; Meyskens, F.L., Jr.; Valanis, B.; Williams, J.H., Jr.; et al. Risk factors for lung cancer and for intervention effects in CARET, the Beta-Carotene and Retinol Efficacy Trial. J. Natl. Cancer Inst. 1996, 88, 1550-1559. [CrossRef]

127. Al-Busafi, S.A.; Bhat, M.; Wong, P.; Ghali, P.; Deschenes, M. Antioxidant therapy in nonalcoholic steatohepatitis. Hepat. Res. Treat. 2012, 2012, 947575. [CrossRef]

128. Sanyal, A.J.; Chalasani, N.; Kowdley, K.V.; McCullough, A.; Diehl, A.M.; Bass, N.M.; Neuschwander-Tetri, B.A.; Lavine, J.E.; Tonascia, J.; Unalp, A.; et al. Pioglitazone, vitamin E, or placebo for nonalcoholic steatohepatitis. N. Engl. J. Med. 2010, 362, 1675-1685. [CrossRef]

129. Biondo, L.A.; Teixeira, A.A.S.; de Oliveira Santos Ferreira, K.C.; Neto, J.C.R. Pharmacological strategies for insulin sensitivity: Thiazolidinediones and metformin. Curr. Pharm. Des. 2020, 10.2174/1381612826666200122124116. [CrossRef]

130. Rena, G.; Hardie, D.G.; Pearson, E.R. The mechanisms of action of metformin. Diabetologia 2017, 60, 1577-1585. [CrossRef]

131. Do, M.T.; Kim, H.G.; Khanal, T.; Choi, J.H.; Kim, D.H.; Jeong, T.C.; Jeong, H.G. Metformin inhibits heme oxygenase-1 expression in cancer cells through inactivation of Raf-ERK-Nrf2 signaling and AMPK-independent pathways. Toxicol. Appl. Pharmacol. 2013, 271, 229-238. [CrossRef] [PubMed]

132. Belfort, R.; Harrison, S.A.; Brown, K.; Darland, C.; Finch, J.; Hardies, J.; Balas, B.; Gastaldelli, A.; Tio, F.; Pulcini, J.; et al. A placebo-controlled trial of pioglitazone in subjects with nonalcoholic steatohepatitis. N. Engl. J. Med. 2006, 355, 2297-2307. [CrossRef] [PubMed]

133. Balas, B.; Belfort, R.; Harrison, S.A.; Darland, C.; Finch, J.; Schenker, S.; Gastaldelli, A.; Cusi, K. Pioglitazone treatment increases whole body fat but not total body water in patients with non-alcoholic steatohepatitis. J. Hepatol. 2007, 47, 565-570. [CrossRef]

134. Ishikawa, H.; Takaki, A.; Tsuzaki, R.; Yasunaka, T.; Koike, K.; Shimomura, Y.; Seki, H.; Matsushita, H.; Miyake, Y.; Ikeda, F.; et al. L-carnitine prevents progression of non-alcoholic steatohepatitis in a mouse model with upregulation of mitochondrial pathway. PLoS ONE 2014, 9, e100627. [CrossRef] [PubMed]

135. Malaguarnera, M.; Gargante, M.P.; Russo, C.; Antic, T.; Vacante, M.; Malaguarnera, M.; Avitabile, T.; Li Volti, G.; Galvano, F. L-carnitine supplementation to diet: A new tool in treatment of nonalcoholic steatohepatitis-a randomized and controlled clinical trial. Am. J. Gastroenterol. 2010, 105, 1338-1345. [CrossRef] [PubMed]

136. Liu, Y.; Wen, P.H.; Zhang, X.X.; Dai, Y.; He, Q. Breviscapine ameliorates CCl4induced liver injury in mice through inhibiting inflammatory apoptotic response and ROS generation. Int. J. Mol. Med. 2018, 42, 755-768. [CrossRef] [PubMed]

137. Loguercio, C.; Festi, D. Silybin and the liver: From basic research to clinical practice. World J. Gastroenterol. WJG 2011, 17, 2288-2301. [CrossRef] [PubMed] 
138. Salomone, F.; Barbagallo, I.; Godos, J.; Lembo, V.; Currenti, W.; Cina, D.; Avola, R.; D'Orazio, N.; Morisco, F.; Galvano, F.; et al. Silibinin Restores NAD(+) Levels and Induces the SIRT1/AMPK Pathway in Non-Alcoholic Fatty Liver. Nutrients 2017, 9, 1086. [CrossRef]

139. Lama, S.; Vanacore, D.; Diano, N.; Nicolucci, C.; Errico, S.; Dallio, M.; Federico, A.; Loguercio, C.; Stiuso, P. Ameliorative effect of Silybin on bisphenol A induced oxidative stress, cell proliferation and steroid hormones oxidation in HepG2 cell cultures. Sci. Rep. 2019, 9, 3228. [CrossRef]

140. Wah Kheong, C.; Nik Mustapha, N.R.; Mahadeva, S. A Randomized Trial of Silymarin for the Treatment of Nonalcoholic Steatohepatitis. Clin. Gastroenterol. Hepatol. 2017, 15, 1940-1949. [CrossRef]

141. Hasegawa, K.; Kokudo, N.; Makuuchi, M.; Izumi, N.; Ichida, T.; Kudo, M.; Ku, Y.; Sakamoto, M.; Nakashima, O.; Matsui, O.; et al. Comparison of resection and ablation for hepatocellular carcinoma: A cohort study based on a Japanese nationwide survey. J. Hepatol. 2013, 58, 724-729. [CrossRef] [PubMed]

142. Poon, R.T.; Fan, S.T.; Ng, I.O.; Lo, C.M.; Liu, C.L.; Wong, J. Different risk factors and prognosis for early and late intrahepatic recurrence after resection of hepatocellular carcinoma. Cancer 2000, 89, 500-507. [CrossRef]

143. Yamamoto, N.; Okano, K.; Kushida, Y.; Deguchi, A.; Yachida, S.; Suzuki, Y. Clinicopathology of recurrent hepatocellular carcinomas after radiofrequency ablation treated with salvage surgery. Hepatol. Res. 2014, 44, 1062-1071. [CrossRef] [PubMed]

144. Tanaka, S.; Mogushi, K.; Yasen, M.; Ban, D.; Noguchi, N.; Irie, T.; Kudo, A.; Nakamura, N.; Tanaka, H.; Yamamoto, M.; et al. Oxidative stress pathways in noncancerous human liver tissue to predict hepatocellular carcinoma recurrence: A prospective, multicenter study. Hepatology 2011, 54, 1273-1281. [CrossRef]

145. Shertzer, H.G.; Clay, C.D.; Genter, M.B.; Schneider, S.N.; Nebert, D.W.; Dalton, T.P. Cyp1a2 protects against reactive oxygen production in mouse liver microsomes. Free Radic. Biol. Med. 2004, 36, 605-617. [CrossRef]

146. Qi, X.; Ng, K.T.; Lian, Q.Z.; Liu, X.B.; Li, C.X.; Geng, W.; Ling, C.C.; Ma, Y.Y.; Yeung, W.H.; Tu, W.W.; et al. Clinical significance and therapeutic value of glutathione peroxidase 3 (GPx3) in hepatocellular carcinoma. Oncotarget 2014, 5, 11103-11120. [CrossRef]

147. Pinter, M.; Peck-Radosavljevic, M. Review article: Systemic treatment of hepatocellular carcinoma. Aliment. Pharmacol. Ther. 2018, 48, 598-609. [CrossRef]

148. Coriat, R.; Nicco, C.; Chereau, C.; Mir, O.; Alexandre, J.; Ropert, S.; Weill, B.; Chaussade, S.; Goldwasser, F.; Batteux, F. Sorafenib-induced hepatocellular carcinoma cell death depends on reactive oxygen species production in vitro and in vivo. Mol. Cancer Ther. 2012, 11, 2284-2293. [CrossRef]

149. Zheng, A.; Chevalier, N.; Calderoni, M.; Dubuis, G.; Dormond, O.; Ziros, P.G.; Sykiotis, G.P.; Widmann, C. CRISPR/Cas9 genome-wide screening identifies KEAP1 as a sorafenib, lenvatinib, and regorafenib sensitivity gene in hepatocellular carcinoma. Oncotarget 2019, 10, 7058-7070. [CrossRef] 